\title{
A Preliminary Study on T-786C Endothelial Nitric Oxide Synthase Gene and Renal Hemodynamic and Blood Pressure Responses to Dietary Sodium
}

\author{
D. R. DENGEL ${ }^{1}$, M. D. BROWN ${ }^{2}$, R. E. FERRELL ${ }^{3}$, T. H. REYNOLDS ${ }^{2}$, \\ M. A. SUPIANO ${ }^{2}$ \\ ${ }^{1}$ School of Kinesiology, University of Minnesota, Minneapolis, Minnesota, 55455 and the \\ Minneapolis Veterans Affairs Medical Center, Minneapolis, Minnesota, 55417, ${ }^{2}$ Department of \\ Internal Medicine, Division of Geriatric Medicine and GRECC, Ann Arbor Veterans Affairs \\ Medical Center, Ann Arbor, Michigan, 48105 and ${ }^{3}$ Department of Human Genetics, University of \\ Pittsburgh Graduate School of Public Health, Pittsburgh, Pennsylvania, 15261, USA
}

Received April 11, 2006

Accepted July 12, 2006

On-line available August 22, 2006

\begin{abstract}
Summary
The purpose of the present study was to examine the role of the T-786C endothelial nitric oxide synthase (eNOS) gene polymorphism on changes in renal hemodynamics and blood pressure due to $\mathrm{Na}^{+}$loading. Twenty-eight older $(63 \pm 1$ years), moderately obese ( $39 \pm 2 \%$ fat) hypertensives had their glomerular filtration rate (GFR), renal plasma flow (RPF), blood pressure (BP) and plasma nitric oxide $\left(\mathrm{NO}_{\mathrm{x}}\right)$ levels determined after eight days of low $(20 \mathrm{mEq})$ and high $(200 \mathrm{mEq}) \mathrm{Na}^{+}$diets. The two $\mathrm{Na}^{+}$diets were separated by a 1-week washout period. Subjects were genotyped for the eNOS-786 site and were grouped on whether they were homozygous or heterozygous for the $\mathrm{C}$ allele $(\mathrm{TC}+\mathrm{CC}, \mathrm{n}=13)$ or only homozygous for the $\mathrm{T}$ allele $(\mathrm{TT}, \mathrm{n}=15)$. The $\mathrm{TC}+\mathrm{CC}$ genotype group had a significantly greater increase in diastolic $(\mathrm{P}=0.021)$ and mean arterial $(\mathrm{P}=0.018) \mathrm{BP}$ and a significant decline in both $\mathrm{RPF}(\mathrm{P}=0.007)$ and $\mathrm{GFR}(\mathrm{P}=0.029)$ compared to the TT genotype group with $\mathrm{Na}^{+}$loading. Furthermore, $\mathrm{Na}^{+}$loading resulted in a significant $(\mathrm{P}=0.036)$ increase in plasma $\mathrm{NO}_{\mathrm{x}}$ in the TT, but not in the $\mathrm{TC}+\mathrm{CC}$ genotype group as well as a trend $(\mathrm{P}=0.051)$ for an increase in urine $\mathrm{NO}_{\mathrm{x}}$ in $\mathrm{TC}+\mathrm{CC}$, but not in the TT genotype group. The increase in $\mathrm{BP}$ during $\mathrm{Na}^{+}$loading in older hypertensives was associated with the eNOS genotype and may be related to changes in renal hemodynamics due to changes in NO metabolism.
\end{abstract}

Key words

Aging $\bullet$ Glomerular filtration rate $\bullet$ Renal plasma flow

\section{Introduction}

A number of endogenous substances have been shown to produce changes in renal hemodynamics. Many of these substances exert their vasodilatory action through endothelial-derived nitric oxide $\left(\mathrm{NO}_{\mathrm{X}}\right)$. It has been 
hypothesized that impairments in endothelial NO generation may be influenced by gene polymorphisms, which ultimately may result in impaired renal hemodynamics (Noiri et al. 2002). The endothelial nitric oxide synthase (eNOS) gene consists of 26 exons and 25 introns located on the long arm of chromosome 7 at $7 \mathrm{q} 35 \rightarrow 36$ (Marsden et al. 1993). In the promoter ( $5^{\prime}$ flanking region), a single nucleotide polymorphism with a $\mathrm{T}$ to $\mathrm{C}$ substitution occurring at nucleotide position -786 (T-786C) has been identified (Karantzoulis-Fegaras et al. 1999, Wang and Wang 2000). Recently, in vitro studies have shown the $\mathrm{C}$ allele to have significantly lower promoter activity compared to the $\mathrm{T}$ allele in a luciferase-based transcription analysis (Nakayama et al. 1999). The C allele influences eNOS transcription, which is consistent with reduced NO production. Therefore, it is possible that the eNOS gene is involved in the regulation of NO in the kidney and may play a role in the variable response of blood pressure and renal hemodynamics to sodium $\left(\mathrm{Na}^{+}\right)$intake in humans.

In humans, there is a great variation in both blood pressure and renal hemodynamic responses to changes in dietary $\mathrm{Na}^{+}$intake, even when the dietary $\mathrm{Na}^{+}$ intake is standardized (Cooperative Research Group 1988). Previously, we reported that $\mathrm{Na}^{+}$-sensitive hypertensive individuals have an increase in glomerular filtration rate (GFR) with an increase in dietary $\mathrm{Na}^{+}$ intake. However, in $\mathrm{Na}^{+}$-resistant individuals, an increase in dietary $\mathrm{Na}^{+}$did not result in any changes in renal hemodynamics (Weir et al. 1995). We undertook the present study to determine if the variability in renal hemodynamics induced by dietary $\mathrm{Na}^{+}$in older hypertensive individuals was related to the eNOS T-786C gene polymorphism. Given that the $\mathrm{C}$ allele has been associated with lower transcription rates, and presumably with a reduction in NO production, we hypothesized that $\mathrm{Na}^{+}$loading would result in a greater increase of blood pressure in these individuals. In addition, we hypothesized that renal hemodynamics might contribute to the differential blood pressure response to $\mathrm{Na}^{+}$loading.

\section{Methods}

\section{Study population}

Twenty-eight older $(63 \pm 1$ years $)$ subjects (10 males and 18 females) with mild hypertension were recruited for this study. Subjects were recruited through a newspaper advertisement, from the University of Michigan Turner Geriatric Clinic, and from the Human
Subjects Core of the University of Michigan Geriatrics Center. All subjects were community dwelling and in good health apart from their hypertension.

Subjects were screened prior to participation with a medical history and physical examination, a complete blood count, and routine blood chemistries, and a urinalysis. Individuals were excluded from the study if they had clinically significant concomitant medical illness such as cardiac, renal (serum creatinine greater than $135 \mathrm{mmol} / \mathrm{l}$ ), hepatic or gastrointestinal disease, or required medications that might affect glucose metabolism or renal function. Individuals with a recent history of smoking or drug or alcohol abuse, or clinically relevant mental disorders were also excluded. Absence of diabetes mellitus was confirmed in all subjects by a 2-hour $75 \mathrm{~g}$ oral glucose tolerance test (American Diabetes Association 1997). Hypertension was defined as a seated systolic blood pressure $\geq 140 \mathrm{~mm} \mathrm{Hg}$ and/or a seated diastolic blood pressure $\geq 90 \mathrm{~mm} \mathrm{Hg}$ (Chobanian et al. 2003).

\section{General study protocol}

At the initial screening visit to determine their eligibility for participation as described above, subjects signed an informed consent form. All studies were performed according to the Declaration of Helsinki, and had been approved by University of Michigan Institutional Review Board. Hypertensive subjects who were being treated with antihypertensive medications were tapered off their medications and were studied following a 4-week period during which no antihypertensive medications were taken. During the tapering period, subjects were given a blood pressure unit to monitor their blood pressure on a daily basis. In addition, patients had their blood pressure taken weekly, by the research staff.

Subjects were randomized in a double-blind design to begin either a 20 or $200 \mathrm{mmol} / \mathrm{l} /$ day $\mathrm{Na}^{+}$diet, which they consumed over an 8 -day period. All meals during the 8-day $\mathrm{Na}^{+}$diet period were prepared by the General Clinical Research Center Metabolic Kitchen at the University of Michigan. The two diets were identical in composition except for the $\mathrm{Na}^{+}$content and consisted of 50-55\% calories as carbohydrate, 30-35\% as fat, $15-20 \%$ as protein and 300 to $350 \mathrm{mg}$ per day of cholesterol. After completion of the first 8-day $\mathrm{Na}^{+}$diet and the associated metabolic and renal tests, the subjects consumed their own diet for a one week washout period and then were switched to the alternative $\mathrm{Na}^{+}$diet, which 
they consumed for a second 8-day period. Compliance with the diet was monitored by $24 \mathrm{~h}$ urine collections for $\mathrm{Na}^{+}$.

\section{Measurement of body composition}

The waist-to-hip circumference ratio (WHR) was calculated as the ratio of the minimal circumference of the abdomen to the circumference of the buttocks at the maximal gluteal protuberance. Body fat, lean body mass (LBM) and percent body fat were determined by dual energy x-ray absorptiometry (DXA, Model DPX-IQ Lunar Radiation Corporation, Madison, WI).

\section{Measurement of blood pressure}

On the eighth day of each $\mathrm{Na}^{+}$diet, blood pressure measurements were made while the subject rested in the seated position, following a 20 min resting period. Systolic, diastolic and mean arterial blood pressure (MABP) were continuously monitored for a 30-min period using Ohmeda 2300 Finapress blood pressure monitor.

\section{Measurement of renal hemodynamics}

Glomerular filtration rate (GFR) and renal plasma flow (RPF) were measured by the clearance of ${ }^{99 m}$ Tc-DTPA $(200 \mu \mathrm{Ci})$ and ${ }^{131}$ I-hippuran $(60 \mu \mathrm{Ci})$, respectively. Briefly, upon arrival at the General Clinical Research Center patients consumed $950 \mathrm{ml}$ of water to establish brisk urine flow after which the subjects were asked to void and resting urine and blood sample were obtained. Following the collection of the resting urine and blood sample an intravenous bolus injection of $100 \mu \mathrm{Ci}$ of ${ }^{99 \mathrm{~m}} \mathrm{Tc}-\mathrm{DTPA}$ and $60 \mu \mathrm{Ci}$ of ${ }^{131} \mathrm{I}$-hippuran was then given and after $60 \mathrm{~min}$, the patient's bladder was emptied, blood samples were withdrawn, and three timed sequential 1-hour urine collections were obtained, after which additional blood samples were withdrawn (Klassen et al. 1992). The ${ }^{99 \mathrm{~m}} \mathrm{Tc}-\mathrm{DTPA}$ and ${ }^{131} \mathrm{I}$-hippuran activity in the samples was determined by liquid scintillation counting. Urinary clearances of ${ }^{99 \mathrm{~m}} \mathrm{Tc}$-DTPA were calculated for each 1-hour collection period as urine activity times urine flow rate divided by average plasma activity. Average plasma activity was calculated as the mean of the plasma values over the interval from the beginning to the end of each urinary collection. The GFR was expressed as the average of the three 1-hour collection values (Klassen et al. 1992). RPF was determined by measuring the disappearance from the serum of $60 \mu \mathrm{Ci}$ of ${ }^{131}$ I-hippuran at precisely $44 \mathrm{~min}$ after injection as previously described (Tauxe et al. 1971). The filtration fraction was calculated by dividing GFR by RPF.

\section{Measurement of plasma and urinary values}

Prior to the determination of renal hemodynamics on each $\mathrm{Na}^{+}$diet blood sample were collected into chilled glass tubes containing heparin sodium, stored on ice, and separated immediately after each study. Plasma and urine samples for aldosterone, renin, creatinine, urea, potassium, protein, chloride, and sodium were measured in the University of Michigan Medical Center Laboratory. Blood samples for measuring $\mathrm{NO}_{\mathrm{X}}$ were drawn directly into a vacuum tubes containing $0.01 \%$ EDTA anticoagulant. Immediately after blood collection, these blood samples were stored temporarily on ice and then centrifuged at $3000 \mathrm{rpm}$ for $20 \mathrm{~min}$ at $4{ }^{\circ} \mathrm{C}$. Plasma isolated from these samples for the $\mathrm{NO}_{\mathrm{X}}$ assay was placed into $1 \mathrm{ml}$ microtubes and frozen at $-80{ }^{\circ} \mathrm{C}$ until analyzed. Before assaying, plasma samples were ultrafiltered to remove protein with single-use filters (Ultrafree-MC Centrifugal Filter, Millipore, Bedford, $\mathrm{MA})$. To eliminate inter-assay variation, the $\mathrm{NO}_{\mathrm{X}}$ assay of the baseline and final plasma samples were performed in the same assay at the end of the study. Since in vivo $\mathrm{NO}$ is rapidly oxidized to the stable end products, $\mathrm{NO}_{2}{ }^{-}$ $+\mathrm{NO}_{3}{ }^{-}$, reported values will represent the total amount of stable plasma $\mathrm{NO}_{\mathrm{X}}$ as measured by a colormetric assay based on the Griess reaction as previously described (Brown et al. 2000).

\section{eNOS genotyping}

Genomic DNA was extracted from leukocytes of the blood sample utilizing a PureGene kit (Gentra Systems, Minneapolis, MN). Subjects were genotyped for the eNOS -786 site using polymerase chain reaction amplification with flanking primers F: 5' - CACCCAGGC CCACCCCAACT-3' and R: 5'-GCCGCAGGTCGAC AGAGA GACT-3'. DNA was denatured for $5 \mathrm{~min}$ at $95^{\circ} \mathrm{C}$ followed by 35 cycles of denaturation $\left(30 \mathrm{~s}, 95^{\circ} \mathrm{C}\right)$, annealing $\left(15 \mathrm{~s}, 54{ }^{\circ} \mathrm{C}\right)$ and extension $\left(30 \mathrm{~s}, 72^{\circ} \mathrm{C}\right)$. The amplicon was digested overnight at $37{ }^{\circ} \mathrm{C}$ using 5 units of MspI followed by electrophoresis for $4 \mathrm{~h}$ in a gel composed of $2 \%$ agarose $+1 \%$ Nusieve (FMC, Inc.). The $\mathrm{T}$ allele yields one fragment of $415 \mathrm{bp}$, and the $\mathrm{C}$ allele yields two fragments of $370 \mathrm{bp}$ and $45 \mathrm{bp}$. Subjects were classified into two different groups based upon whether they were homozygous or heterozygous for the $\mathrm{C}$ allele $(\mathrm{TC}+\mathrm{CC}, \mathrm{n}=13)$ or only homozygous for the $\mathrm{T}$ allele (TT, $\mathrm{n}=15)$. 
Table 1. Physical characteristics of older hypertensives by $\mathrm{T}-786 \mathrm{C}$ polymorphism $(\pi, \mathrm{TC}+\mathrm{CC})$ in the $5^{\prime}$-flanking region of the eNOS gene

\begin{tabular}{llll}
\hline & TC+CC & TT & P value \\
\hline Number & 13 & 15 & \\
Gender $(M / F)$ & $4 / 9$ & $6 / 9$ & 0.611 \\
Ethnicity & $2 / 11$ & $3 / 12$ & 0.750 \\
Age (years) & $63.7 \pm 2.0$ & $62.5 \pm 2.0$ & 0.676 \\
Height (cm) & $165.1 \pm 3.2$ & $170.0 \pm 1.9$ & 0.187 \\
Weight (kg) & $80.2 \pm 4.5$ & $82.0 \pm 3.7$ & 0.752 \\
Body fat $(\%)$ & $39.2 \pm 2.3$ & $38.2 \pm 2.3$ & 0.751 \\
Waist:hip ratio & $0.86 \pm 0.02$ & $0.87 \pm 0.02$ & 0.704 \\
\hline
\end{tabular}

Data are mean \pm S.E.M. Ethnicity (African-American/Caucasian)

\section{Statistical analysis}

Data were analyzed using Statview (Abacus Concepts, Inc., Berkeley, CA). An alpha level of 0.05 was accepted for statistical significance. Comparisons of the physical characteristics of the two eNOS groups were made using analysis of variance (ANOVA). A two-way repeated measures ANOVA with eNOS genotype group (TT and $\mathrm{TC}+\mathrm{CC})$ as one variable and $\operatorname{diet}\left(\right.$ low $\mathrm{Na}^{+}$and high $\mathrm{Na}^{+}$) as the other was utilized to examine within and between group differences. All data are reported as means \pm S.E.M.

\section{Results}

Twenty-eight older ( $63.0 \pm 1.4$ years), moderately overweight $(38.7 \pm 1.6 \%$ fat $)$ subjects with essential hypertension were studied (Table 1). When these subjects were divided into groups based upon the T-786C polymorphism (TT, TC, CC), 15 individuals were TT and 12 individuals were TC. One subject (3\%) was a CC homozygote, which agrees with the reported frequency of the CC genotype (Yoshimura et al. 2000). Based on available data, the frequency of the CC genotype in the population is between 0.02 and 0.10 . Thus, we did not have adequate statistical power to include a separate $\mathrm{CC}$ genotype group. Furthermore, the $\mathrm{C}$ allele is considered to have deleterious cardiovascular effects, with $\mathrm{CC}$ and TC genotype group demonstrating similar responses that are different from the group with the TT genotype (Nakayama et al. 1999, Zanchi et al. 2000, Rossi et al. 2003). Thus, it appears appropriate from a mechanistic perspective to group the $\mathrm{C}$ allele carriers into a combined $\mathrm{TC}+\mathrm{CC}$ genotype group.
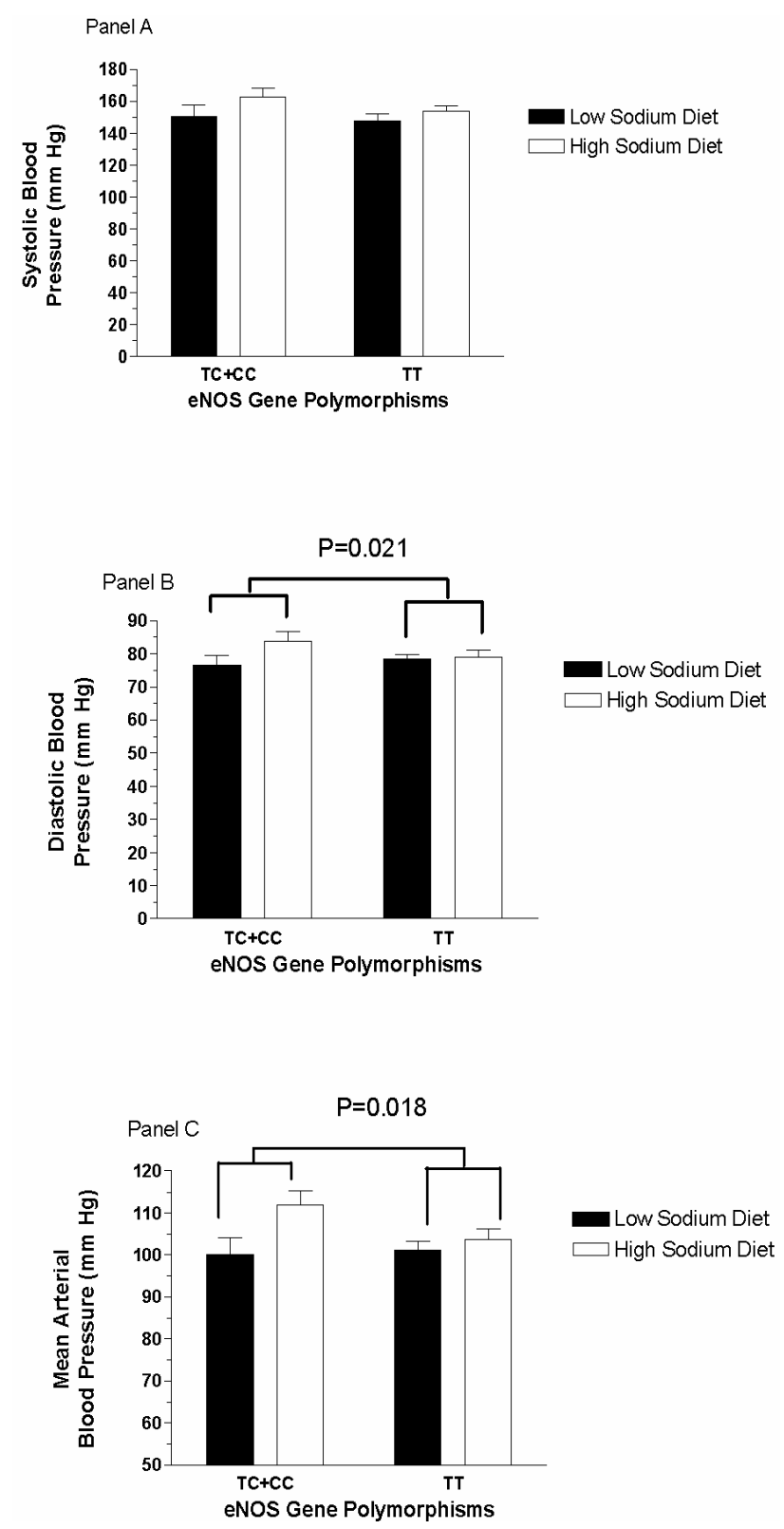

Fig. 1. Mean arterial (Panel $A)$, systolic (Panel $B$ ) and diastolic (Panel C) blood pressure on low (20 mEq/day) (open bar) and high (200 mEq/day) (solid bar) sodium $\left(\mathrm{Na}^{+}\right)$intake in $\mathrm{TC}+\mathrm{CC}$ $(n=13)$ and TT $(n=15)$ eNOS gene polymorphisms.

Therefore, in the present study, subjects were categorized into a combined $\mathrm{TC}+\mathrm{CC}$ genotype group and compared to the TT genotype group. The distribution of eNOS genotypes in this group of older hypertensive individuals was $54 \% \mathrm{TT}$, and $46 \% \mathrm{TC}+\mathrm{CC}$, which is similar to the distribution in the general population (Zanchi et al. 2000, Rossi et al. 2003). There were no statistically significant differences in age, weight, body mass index or percentage body fat between the two eNOS genotype groups (Table 1). 

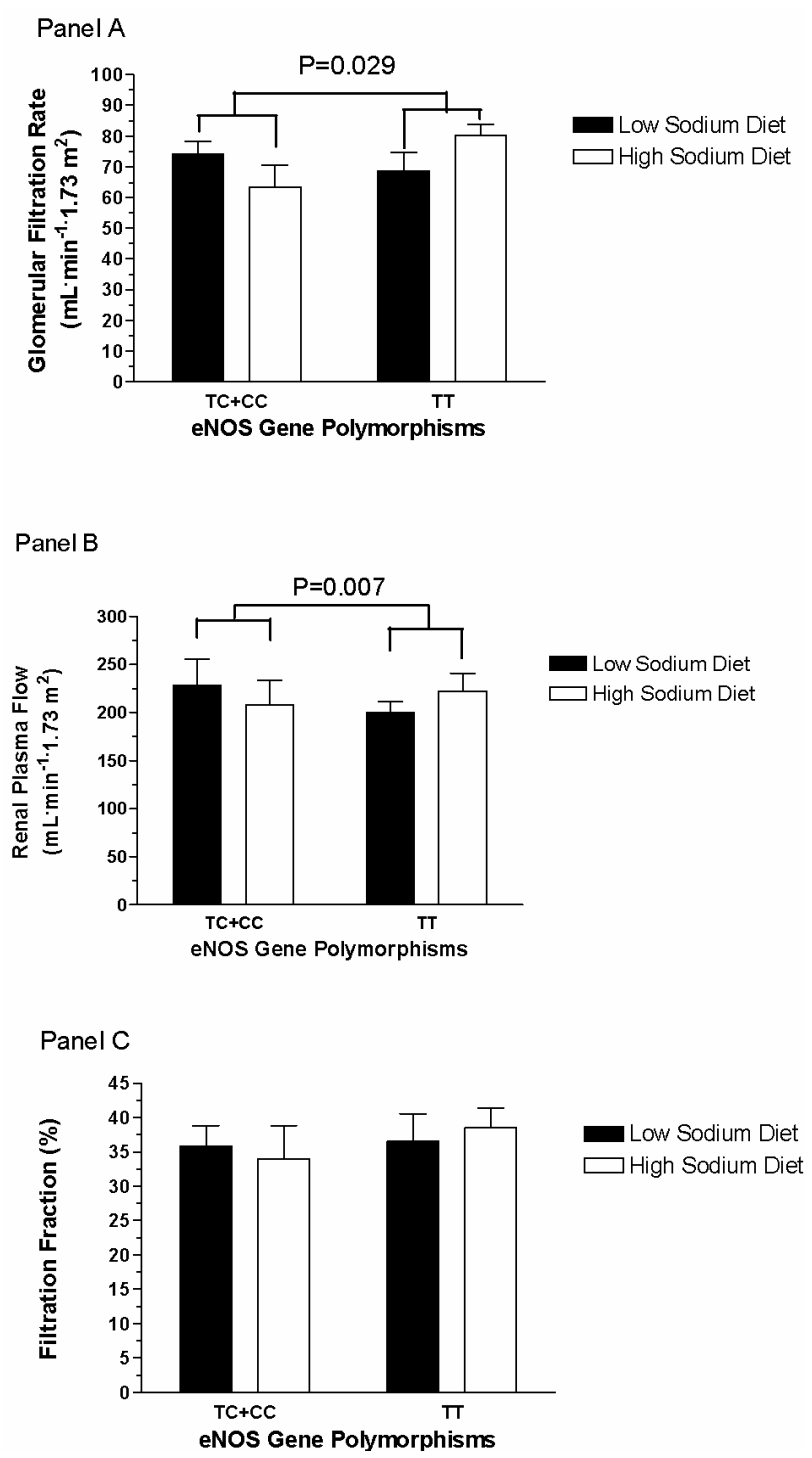

Fig. 2. Glomerular filtration rate (Panel $A$ ), renal plasma flow (Panel B) and filtration fraction (Panel $C$ ) in individuals with the $\mathrm{TC}+\mathrm{CC}(\mathrm{n}=13)$ and $\mathrm{TT}(\mathrm{n}=15)$ eNOS gene polymorphisms on low (20 mEq/day) (open bar) and high (200 mEq/day) (solid bar) sodium $\left(\mathrm{Na}^{+}\right)$intake.

\section{Blood pressure}

Although there was no significant $(\mathrm{P}=0.411)$ interaction of the eNOS gene polymorphism and dietary $\mathrm{Na}^{+}$on systolic blood pressure (Figure 1, Panel A) there was a significant $(\mathrm{P}=0.021)$ interaction of the eNOS gene polymorphism and dietary $\mathrm{Na}^{+}$on diastolic blood pressure (Figure 1, Panel B), indicating that $\mathrm{TC}+\mathrm{CC}$ genotype individuals increased their diastolic blood pressure in response to $\mathrm{Na}^{+}$loading, while the TT genotype individuals did not. Similarly, there was a significant $(\mathrm{P}=0.018)$ interaction of the eNOS gene polymorphism and dietary $\mathrm{Na}^{+}$on mean arterial blood pressure (Figure 1, Panel C), indicating that the $\mathrm{TC}+\mathrm{CC}$ genotype individuals increased their mean arterial blood pressure in response to $\mathrm{Na}^{+}$loading, while the TT genotype individuals did not.

\section{Renal hemodynamics}

There was a significant interaction between eNOS gene polymorphism and dietary $\mathrm{Na}^{+}$on the glomerular filtration rate $(\mathrm{P}=0.029)$ (Fig. 2A), demonstrating an increase in GFR with $\mathrm{Na}^{+}$loading in TT genotype individuals, while GFR decreased with $\mathrm{Na}^{+}$ loading in $\mathrm{TC}+\mathrm{CC}$ genotype individuals. Similarly, there was a significant $(\mathrm{P}=0.007)$ interaction between dietary $\mathrm{Na}^{+}$and eNOS polymorphism on renal plasma flow indicating that the $\mathrm{TC}+\mathrm{CC}$ genotype individuals reduced their RPF in response to $\mathrm{Na}^{+}$loading, while the TT genotype individuals increased their RPF in response to $\mathrm{Na}^{+}$loading (Fig. 2B). There was no interaction between dietary $\mathrm{Na}^{+}$and eNOS gene polymorphism on filtration fraction $(\mathrm{P}=0.493)$ (Fig. 2C). Although $\mathrm{Na}^{+}$ clearance was not significantly different between $\mathrm{TT}$ and $\mathrm{TC}+\mathrm{CC}$ genotype groups, as expected there was a significant $(\mathrm{P}<0.0001)$ increase in both groups in response to $\mathrm{Na}^{+}$loading (Table 2).

\section{Plasma and urine values}

The mean plasma $\mathrm{Na}^{+}$levels were significantly $(\mathrm{P}=0.027)$ higher during the high $\mathrm{Na}^{+}$diet in both groups (Table 2). In addition, the increase in dietary $\mathrm{Na}^{+}$resulted in a significant decrease in plasma levels of urea, creatinine and aldosterone in both groups (Table 2). There was a trend $(\mathrm{P}=0.072)$ for the $\mathrm{TC}+\mathrm{CC}$ genotype group to have higher plasma renin levels than the TT genotype group on both high and low $\mathrm{Na}^{+}$diets (Table 2 ).

As expected, the mean $24 \mathrm{~h}$ urinary $\mathrm{Na}^{+}$ excretion was significantly $(\mathrm{P}<0.0001)$ higher during the high $\mathrm{Na}^{+}$diet in both groups (Table 2). There was also a significant $(\mathrm{P}<0.0001)$ increase in urinary volume in both genotype groups with the increase in dietary $\mathrm{Na}^{+}$(Table 2). There was a significant interaction between eNOS genotype and dietary $\mathrm{Na}^{+}$intake in those individuals with the $\mathrm{TC}+\mathrm{CC}$ genotype increasing their urinary output to a greater degree than those individuals with the TT genotype. There was no change in urinary creatinine or protein levels with the change in dietary $\mathrm{Na}^{+}$(Table 2). There was no main effect of eNOS genotype or dietary $\mathrm{Na}^{+}$on plasma or urinary creatinine levels (Table 2 ).

There was a significant interaction for dietary $\mathrm{Na}^{+}$and the eNOS gene polymorphism on plasma $\mathrm{NO}_{\mathrm{X}}$ levels (Table 2). Following the high $\mathrm{Na}^{+}$diet plasma, 
Table 2. Plasma and urinary values in older hypertensives on low and high sodium ( $\left.\mathrm{Na}^{+}\right)$diets by $\mathrm{T}-786 \mathrm{C}$ polymorphism $(\mathrm{TT}, \mathrm{TC}+\mathrm{CC})$ in the $5^{\prime}$-flanking region of the eNOS gene.

\begin{tabular}{|c|c|c|c|c|c|c|c|}
\hline & \multicolumn{2}{|c|}{$T C+C C(n=13)$} & \multicolumn{2}{|c|}{ TT $(n=15)$} & \multicolumn{3}{|c|}{ P-Value } \\
\hline & Low $\mathrm{Na}^{+}$ & $\mathrm{High} \mathrm{Na}^{+}$ & Low Na ${ }^{+}$ & $\mathrm{High} \mathrm{Na}^{+}$ & $\begin{array}{l}\text { Group } \\
\text { Effect }\end{array}$ & $\begin{array}{c}\text { Diet } \\
\text { Effect }\end{array}$ & $\begin{array}{c}\text { Interaction } \\
\text { Effect }\end{array}$ \\
\hline \multicolumn{8}{|c|}{ Plasma Variables } \\
\hline $\begin{array}{l}\text { Sodium } \\
(\mathrm{mmol} / \mathrm{l})\end{array}$ & $138.0 \pm 0.5$ & $138.5 \pm 0.3$ & $138.5 \pm 0.4$ & $139.5 \pm 0.5$ & 0.205 & 0.027 & 0.422 \\
\hline $\begin{array}{l}\text { Urea } \\
(\mathrm{mmol} / \mathrm{l})\end{array}$ & $5.3 \pm 0.2$ & $4.5 \pm 0.2$ & $5.6 \pm 0.4$ & $4.5 \pm 0.2$ & 0.838 & $<0.0001$ & 0.551 \\
\hline $\begin{array}{l}\text { Creatinine } \\
(\mu \mathrm{mol} / \mathrm{l})\end{array}$ & $84.9 \pm 3.5$ & $79.6 \pm 4.4$ & $83.1 \pm 4.4$ & $79.6 \pm 4.4$ & 0.877 & 0.001 & 0.423 \\
\hline $\begin{array}{l}\text { Aldosterone } \\
(\mathrm{pmol} / \mathrm{l})\end{array}$ & $543.7 \pm 91.5$ & $174.8 \pm 38.8$ & $502.1 \pm 83.2$ & $202.5 \pm 36.0$ & 0.927 & $<0.0001$ & 0.614 \\
\hline $\begin{array}{l}\text { Renin } \\
(n g / s)\end{array}$ & $1.16 \pm 0.22$ & $0.39 \pm 0.28$ & $2.71 \pm 0.08$ & $0.20 \pm 0.03$ & 0.072 & $<0.0001$ & 0.425 \\
\hline $\begin{array}{l}\text { Plasma } N O_{x} \\
(\mu \mathrm{mol} / \mathrm{l})\end{array}$ & $18.5 \pm 2.8$ & $17.2 \pm 3.5$ & $17.7 \pm 3.6$ & $23.6 \pm 4.7$ & 0.578 & 0.158 & 0.036 \\
\hline \multicolumn{8}{|c|}{ Urine Variables } \\
\hline $\begin{array}{l}\text { Volume } \\
\text { (ml/day) }\end{array}$ & $1785 \pm 158$ & $2262 \pm 180$ & $1888 \pm 166$ & $2038 \pm 124$ & 0.779 & $<0.0001$ & 0.014 \\
\hline $\begin{array}{l}\text { Sodium } \\
\text { (mmol/day) }\end{array}$ & $30.5 \pm 3.3$ & $197.0 \pm 14.3$ & $42.3 \pm 11.6$ & $185.5 \pm 6.8$ & 0.988 & $<0.0001$ & 0.215 \\
\hline $\begin{array}{l}\text { Creatinine } \\
\text { (mmol/day) }\end{array}$ & $12.0 \pm 0.9$ & $12.1 \pm 0.9$ & $11.3 \pm 0.7$ & $11.7 \pm 0.7$ & 0.605 & 0.593 & 0.717 \\
\hline $\begin{array}{l}\text { Protein } \\
(\mathrm{g} / \mathrm{l})\end{array}$ & $0.05 \pm 0.01$ & $0.05 \pm 0.01$ & $0.03 \pm 0.01$ & $0.04 \pm 0.01$ & 0.418 & 0.570 & 0.417 \\
\hline $\begin{array}{l}\text { Urine } N O_{x} \\
(\mu \mathrm{mol} / \mathrm{l})\end{array}$ & $20.4 \pm 4.2$ & $28.6 \pm 5.3$ & $27.6 \pm 5.6$ & $24.5 \pm 7.0$ & 0.838 & 0.359 & 0.051 \\
\hline
\end{tabular}

Values are means \pm S.E.M.

$\mathrm{NO}_{\mathrm{X}}$ levels significantly $(\mathrm{P}=0.036)$ increased in the TT genotype group compared with the $\mathrm{TC}+\mathrm{CC}$ genotype group (5.0 \pm 2.3 vs. $-1.3 \pm 2.1 \mu \mathrm{mol} / 1$, respectively). There was a significant interaction between dietary $\mathrm{Na}^{+}$and the eNOS gene polymorphism on urine $\mathrm{NO}_{\mathrm{X}}$ levels (Table 2). There was a trend $(\mathrm{P}=0.051)$ for the $\mathrm{TC}+\mathrm{CC}$ genotype group to increase their urine $\mathrm{NO}_{\mathrm{X}}$ levels in response to $\mathrm{Na}^{+}$loading while the TT genotype group maintained urine $\mathrm{NO}_{\mathrm{X}}$ levels during $\mathrm{Na}^{+}$loading (Table 2).

\section{Discussion}

The present study demonstrates an association between the T-786C polymorphism in the eNOS gene promoter and changes in renal hemodynamics and mean arterial blood pressure in response to dietary $\mathrm{Na}^{+}$loading in older hypertensives. Individuals homozygous for the $\mathrm{T}$ allele had no significant increase in their MABP in response to the increase in dietary $\mathrm{Na}^{+}$; however, individuals with the $\mathrm{C}$ allele had a significant increase in MABP with $\mathrm{Na}^{+}$loading. One possible explanation for the elevation of MABP with the increase in dietary $\mathrm{Na}^{+}$in individuals with the $\mathrm{C}$ allele may be the abnormal response in GFR with $\mathrm{Na}^{+}$loading. In individuals homozygous for the $\mathrm{T}$ allele, the increase of dietary $\mathrm{Na}^{+}$ resulted in an enhanced GFR. However, in individuals 
with the $\mathrm{C}$ allele, the increase in dietary $\mathrm{Na}^{+}$resulted in a decline in GFR. Typically, higher dietary $\mathrm{Na}^{+}$results in an increase in GFR (Laragh and Sealey 1992). This change in GFR may be mediated in part by changes in renal renin secretion and thus angiotensin II formation (Laragh and Sealey 1992). Normally an increase in dietary $\mathrm{Na}^{+}$intake depresses renal renin secretion while a reduction in dietary $\mathrm{Na}^{+}$intake increases renal renin secretion (Sealey et al. 1972). Although individuals homozygous for the $\mathrm{T}$ allele and individuals with the $\mathrm{C}$ allele in the present study both demonstrated a reduction in plasma renin levels with $\mathrm{Na}^{+}$loading. However, there was a trend for those individuals homozygous for the $\mathrm{T}$ allele to have higher renin levels during the low $\mathrm{Na}^{+}$diet and lower renin levels during $\mathrm{Na}^{+}$loading than those with the $\mathrm{C}$ allele. Therefore, those individuals homozygous for the $\mathrm{T}$ allele demonstrated a greater overall change in renal renin secretion with the change in dietary $\mathrm{Na}^{+}$, which may explain the ability of this group to preserve blood pressure in response to an increase in dietary $\mathrm{Na}^{+}$intake.

The mechanism of this abnormal response in RPF and GFR is not known, but it is possible that endothelial-derived NO plays a role. Nitric oxide exerts a powerful influence on the regulation of RPF and $\mathrm{Na}^{+}$ excretion. NO regulates the glomerular microcirculation by modulating afferent blood vessels (Wang and Wang 2000). It relaxes mesangial cells and contributes to the regulation of renal $\mathrm{Na}^{+}$excretion and the release of renin (Wang and Wang 2000). Of all the tissues that are sensitive to the effects of $\mathrm{NO}$, the renal vasculature appears to be the most sensitive (Majid et al. 1999, Zou and Cowley 1997, Zuckerman et al. 1997). In the present study, individuals with the $\mathrm{T}$ allele had a significant increase in plasma levels of $\mathrm{NO}_{\mathrm{x}}$ with the increase in dietary $\mathrm{Na}^{+}$, while those individuals with the $\mathrm{C}$ allele had little or no change in plasma $\mathrm{NO}_{\mathrm{x}}$ levels. The elevated plasma $\mathrm{NO}_{\mathrm{X}}$ level in individuals with the $\mathrm{T}$ allele may be indicative of an increase in systemic and/or renal $\mathrm{NO}_{\mathrm{X}}$ production. This increased $\mathrm{NO}_{\mathrm{X}}$ production could result in vasodilation of the vascular beds resulting in the increase of RPF and GFR and an overall maintenance of blood pressure during $\mathrm{Na}^{+}$loading. Alteration in the $\mathrm{NO}_{\mathrm{X}}$ system may lead to impairment in renal hemodynamics and reduced $\mathrm{Na}^{+}$excretion during elevation in dietary $\mathrm{Na}^{+}$ resulting in an elevation in blood pressure. Shultz and Tolins (1993) demonstrated that the NO system directly modulates renal hemodynamics and $\mathrm{Na}^{+}$excretion in Sprague-Dawley rats. These investigators measured GFR, RPF, and urinary $\mathrm{Na}^{+}$excretion during $\mathrm{NO}$ synthase inhibition. In a dose-dependent fashion, NO synthase inhibition resulted in renal vasoconstriction, and reduced GFR and RPF. Shultz and Tolins (1993) found that $\mathrm{Na}^{+}$ loading significantly increased total serum and urinary $\mathrm{NO}_{\mathrm{X}}$ excretion suggesting that $\mathrm{Na}^{+}$loading increases $\mathrm{NO}_{\mathrm{X}}$ production. Other studies have shown a direct relationship between changes in renal arterial pressure and renal $\mathrm{NO}_{\mathrm{X}}$ production and that these changes paralleled those in urinary $\mathrm{Na}^{+}$excretion (Hu and Manning 1995, Majid et al. 1993, Majid and Navar 1997). Recently, Majid et al. (1999) found that dosedependent changes in renal arterial pressure were correlated with changes in renal cortex $\mathrm{NO}_{\mathrm{x}}$ production and in urinary excretion of $\mathrm{Na}^{+}$and total nitrates.

Tracer studies in humans have demonstrated that $50 \%$ of systemic nitrates originate from the $\mathrm{NO}_{\mathrm{X}}$ synthesis substrate, L-arginine (Castillo et al. 1993, Rhodes et al. 1995) and that $\mathrm{NO}_{\mathrm{X}}$ synthase inhibition induces a pronounced reduction of urinary nitrates (Boger et al. 1996). Although it is clear that nitrate is synthesized by mammalian endothelial cells as a result of eNOS activity, increasing dietary nitrate intake also increases urinary nitrate excretion (Granger et al. 1991). However, in the present study the participants were on a stable diet for 8 days before plasma $\mathrm{NO}_{\mathrm{X}}$ samples were drawn. Baylis et al. (1998) have demonstrated that if samples are collected after a stable period of fasting $(>10 \mathrm{~h})$ and during a controlled nitrate diet, plasma and urine levels of nitrates provide an estimate of total body $\mathrm{NO}_{\mathrm{X}}$ generation, but not an estimation of biologically active $\mathrm{NO}_{\mathrm{X}}$.

Although this is a preliminary study with a small number, it may be that the increase in MABP during $\mathrm{Na}^{+}$ loading in the $\mathrm{TC}+\mathrm{CC}$ group may be related to impaired NO production and a fall in RPF and GFR. It is more than likely that multiple genes influence the renal hemodynamics response to dietary $\mathrm{Na}^{+}$. Thus, the influence of any single gene on renal hemodynamic responses during alterations in dietary $\mathrm{Na}^{+}$is likely to be small. However, the eNOS T-786C gene polymorphism is a particularly attractive candidate because it has been shown to alter gene promoter and transcriptional activities. Future studies will be needed to examine the mechanisms that contribute to the observed interaction between changes in dietary $\mathrm{Na}^{+}$induced alterations in renal hemodynamics and the eNOS genotype.

\section{Acknowledgements}

Supported by National Institutes of Health Research 
Scientist Development Award in Aging KO1 AG0072301 (DRD), National Institutes of Health grants U10HL54526 (REF) and K24 AG 000924 (MAS), Department of Veterans Affairs Medical Research Service (MAS) and Geriatric Research, Education and Clinical Center (DRD,
MAS) at Ann Arbor, University of Michigan, Claude D. Pepper Older Americans Independence Center (AG08808), University of Michigan Clinical Research Center (RR-00042).

\section{References}

AMERICAN DIABETES ASSOCIATION: Report of the expert committee on the diagnosis and classification of diabetes mellitus. Diabetes Care 20: 1183-1197, 1997.

BAYLIS C, VALLANCE P: Measurement of nitrite and nitrate in plasma and urine - what does this measure tell us about the activity of endogenous the nitric oxide system. Curr Opin Nephrol Hypertens 7: 59-62, 1998.

BOGER RH, BODE-BOGER SM, GERECKE U, GUTZKI FM, TSIKAS D, FROLICH JC: Urinary NO3- excretion as an indicator of nitric oxide formation in vivo during oral administration of L-arginine or L-NAME in rats. Clin Exp Pharmacol Physiol 23: 11-15, 1996.

BROWN MD, SRINIVASAN M, HOGIKYAN RV, DENGEL DR, GLICKMAN SG, GALECKI A, SUPIANO MA: Nitric oxide biomarkers increase during exercise-induced vasodilation in the forearm. Int J Sports Med 21: 83$89,2000$.

CASTILLO L, DEROJAS TC, CHAPMAN TE, VOGT J, BURKE JF, TANNENBAUM SR, YOUNG VR: Splanchnic metabolism of dietary arginine in relation to nitric oxide synthesis in normal adult man. Proc Natl Acad Sci USA 90: 193-197, 1993.

CHOBANIAN AV, BAKRIS GL, BLACK HR, CUSHMAN WC, GREEN LA, IZZO JL Jr, JONES DW, MATERSON BJ, OPARIL S, WRIGHT JT Jr, ROCCELLA EJ: Joint National Committee on Prevention, Detection, Evaluation, and Treatment of High Blood Pressure. National Heart, Lung, and Blood Institute. National High Blood Pressure Education Program Coordinating Committee. Seventh report of the Joint National Committee on Prevention, Detection, Evaluation, and Treatment of High Blood Pressure. Hypertension 42: 1206-1252, 2003.

COOPERATIVE RESEARCH GROUP: Intersalt, 1986: an international cooperative study on the relation of blood pressure to sodium and potassium excretion. $B r$ Med $J$ 297: 319-328, 1988.

GRANGER DL, HIBBS JB Jr, BROADNAX LM: Urinary nitrite excretion in relation to murine macrophage activation. J Immunol 146: 1294-1302, 1991.

HU L, MANNING, RD: Role of nitric oxide in regulation of long-term pressure natriuresis relationship in Dahl rats. $\mathrm{Am}$ J Physiol 268: H2375-H2383, 1995.

KARANTZOULIS-FEGARAS F, ANTONIOU H, LAI SL, KULKARNI G, D'ABREO C, WONG GK, MILLER TL, CHAN Y, ATKINS J, WANG Y, MARSDEN PA: Characterization of the human endothelial nitric-oxide synthase promoter. J Biol Chem 274: 3076-3093, 1999.

KLASSEN DK, WEIR MR, BUDDEMEYER EU: Simultaneous measurements of glomerular filtration rate by two radioisotopic methods in patients without renal impairment. J Am Soc Nephrol 3: 108-112, 1992.

LARAGH JH, SEALEY JE: Renin-angiotensin-aldosterone system and the renal regulation of sodium, potassium, and blood pressure homeostasis. In: Handbook of Physiology, Renal Physiology, E. E. WINDHAGER (ed), Oxford University Press, New York, 1992, pp 1409-1541.

MAJID DS, NAVAR LG: Nitric oxide in the mediation of pressure natriuresis. Clin Exp Pharmacol Physiol 24: 595599, 1997.

MAJID DS, WILLIAMS A., KADOWITZ PJ, NAVAR LG: Renal responses to intra-arterial administration of nitric oxide donor in dogs. Hypertension 22: 535-541, 1993.

MAJID DS, SAID KE, OMORO SA: Responses to acute changes in arterial pressure on renal medullary nitric oxide activity in dogs. Hypertension 34: 832-836, 1999. 
MARSDEN PA, HENG HH, SCHERER SW, STEWART RJ, HALL AV, SHI XM, TSUI LC, SCHAPPERT KT: Structure and chromosomal localization of the human constitutive endothelial nitric oxide synthase gene. $J$ Biol Chem 268: 17478-17488, 1993.

NAKAYAMA M, HIROFUMI Y, YOSHIMURA M, SHIMASAKI Y, KUGIYAMA K, OGAWA H, MOTOYAMA T, SAITO Y, OGAWA Y, MIYAMOTO Y, NAKAO K: T-786-->C mutation in the 5'-flanking region of the endothelial nitric oxide synthase gene is associated with coronary spasm. Circulation 99: 2864-2870, 1999.

NOIRI E, SATOH H, TAGUCHI J, BRODSKY SV, NAKAO A, OGAWA Y, NISHIJIMA S, YOKOMIZO T, TOKUNAGA K, FUJITA T: Association of eNOS Glu296Asp polymorphism with end-stage renal disease. Hypertension 40: 535-540, 2002.

RHODES PM, LEONE AM, FRANCIS PL, STRUTHERS AD, MONCADA S: The L-arginine-nitric oxide pathway is the major source of plasma nitrates in human subjects. Biochem Biophys Res Commun 209: 590-596, 1995.

ROSSI GP, TADDEI S, VIRDIS A, CAVALLIN M, GHIADONI L, FAVILLA S, VERSARI D, SUDANO I, PESSINA AC, SALVETTI A: The T-786C and Glu298Asp polymorphisms of the endothelial nitric oxide gene affect the forearm blood flow responses of Caucasian hypertensive patients. J Am Coll Cardiol 41: 938-945, 2003.

SEALEY JE, GERTEN-BANES J, LARAGH JH: The renin system: variations in man measured by radioimmunoassay or bioassay. Kidney Int 1: 240-253, 1972.

SHULTZ PJ, TOLINS JP: Adaptation to increased dietary salt intake in rats. J Clin Invest 91: 642-650, 1993.

TAUXE WN, MAHER F, TAYLOR WF: Effective renal plasma flow: estimation from theoretical volumes of distribution of intravenously injected ${ }^{131}$ I-orthoiodohippurate. Mayo Clin Proc 416: 524-531, 1971.

WANG XL, WANG J: Endothelial nitric oxide synthase gene sequence variations and vascular disease. Mol Genet Metab 70: 241-251, 2000.

WEIR MR, DENGEL DR, BEHRENS MT, GOLDBERG AP: Salt-induced increases in systolic blood pressure affect renal hemodynamics and proteinuria. Hypertension 25: 1339-1344, 1995.

YOSHIMURA M, YASUE H, NAKAYAMA M, SHIMASAKI Y, OGAWA H, KUGIYAMA K, SAITO Y, MIYAMOTO Y, OGAWA Y, KANESHIGE K, HIRAMATSU H, YOSHIOKA T, KAMITANI S, TERAOKA H, NAKAO K: Genetic risk factors for coronary artery spasm: significance of endothelial nitric oxide synthase Gene T-786-C and missense Glu298Asp variants. J Investig Med 48: 367-374, 2000.

ZANCHI A, MOCZULSKI DK, HANNA LS, WANTMAN M, WARRAM JH, KROLEWSKI AS: Risk of advanced diabetic nephropathy in type 1 diabetes is associated with endothelial nitric oxide synthase gene polymorphism. Kidney Int 57: 405-13, 2000.

ZOU AP, COWLEY AE: Nitric oxide in renal cortex and medulla: an in vivo microdialysis study. Hypertension 29: 194-198, 1997.

ZUCKERMAN A, CHANDER PN, ZEBALLOS GA, STIER CTL: Regional renal nitric oxide release in stroke-prone spontaneously hypertensive rats. Hypertension 30: 1479-1486, 1997.

\section{Corresponding author}

Donald R. Dengel, University of Minnesota, 1900 University Avenue S.E., 110 Cooke Hall, Minneapolis, MN 55455, USA. Fax: (612) 625-9380. E-mail: denge001@umn.edu 